\title{
OPTIMIZING BIODEGRADABLE POT (BIOPOT) COMPOSITION FOR PAPAYA (Carica papaya L.) NURSERY
}

\author{
${ }^{1 *}$ Aniek Iriany, ${ }^{2}$ Mochammad Chanan, ${ }^{1}$ Faridlotul Hasanah, ${ }^{1}$ Muhammad Halim Prasetyo \\ ${ }^{1}$ Department of Agrotechnology, University of Muhammadiyah Malang, Indonesia. \\ ${ }^{2}$ Department of Forestry, University of Muhammadiyah Malang, Indonesia. \\ *Corresponding Author
}

ORCiD: 0000-0001-6735-7440

DOI: https://doi.org/10.51193/IJAER.2021.7509

Received: 27 Oct. 2021 / Accepted: 03 Nov. 2021 / Published: 12 Nov. 2021

\begin{abstract}
Plant nursery is an important cultivation phase to improve the quality of papaya (Carica papaya L.). However, poly bag used for the seedling container would contaminate the environment and it potentially inhibits the root growth. BioPot (Biodegradable pot) is a suitable alternative seedling container considering its plantable characteristic. This research aimed to optimize the composition of BioPot for papaya nursery. This research was conducted using simple Randomized Complete Block Design with 1 control (60\% water hyacinth and $40 \%$ banana pseudostem) and 7 treatments (50\% water hyacinth and $40 \%$ banana pseudostem combined with $10 \%$ nutrient sources i.e cow, goat, chicken, and or Tithonia diversifolia manure). The data were analyzed by using F-test, followed by Tukey HSD test with 5\% significance and response surface analysis. The optimation results formed relatively flat curve from all response variables indicating that the obtained response has reached optimum results at all BioPot compositions with various nutrient sources. The findings confirmed that various nutrient sources in this research could be used in BioPot formulation for papaya nursery, considering the availability and accessibility of the local nutrient sources. This research provided information regarding the formulation of biodegradable pot to produce good and environmentally friendly seedlings while minimalizing and eliminating the negative impact to the environment.
\end{abstract}

Keywords: Biodegradable pot, Biocontainer, Papaya, Seedling 
International Journal of Agriculture and Environmental Research

ISSN: $2455-6939$

Volume: 07, Issue: 05 "September-October 2021"

\section{INTRODUCTION}

Papaya belongs to the group of tropical fruits and is endeavored to be excellent fruit to cultivate in Indonesia. In fact, Indonesia has positioned the $4^{\text {th }}$ world rank as the biggest papaya producer in 2017, with 875,112 tons of total production, and has penetrated to the $2^{\text {nd }}$ world rank as the biggest yields constituting 92.1 tons/ha despite the depletion of harvesting area from 9,999 to 9,497 ha [1]. Indonesian papaya exportin 2015 merely gained 15.4 tons, but it significantly increased in 2016 to be 35.6 tons and followed by a dramatic decline in 2017 to be 16 tons [2]. This has clarified that further improvement to advance the quality of papaya is still of great necessity. Accordingly, the best solution to take is by creating a good plant nursery for the sake of optimal production, which is supposed to result in high-quality outcomes.

Papaya reproduction process is totally dependent on seeds. Generally, papaya is sexually propagated through seeds; while asexual propagation through the vegetative parts of plant has not been proved successful on a commercial scale [3]. In general, papaya nursery is frequently grown on polybag as these edling pot or container before it is moved to the farming area. Poly bags are made of plastic, which is considered the most notorious weakness. Plastic pollution becomes a major concern not only in the terrestrial environment but also in the coastal and marine environment due to its unique characteristics compared with other pollutants [4-5]. It is explained by improper handling and disposal of plastics causing $25 \%$ of annually produced plastic that ends up in the environment [6]. In fact, plastic has non-biodegradable properties that result in polluting and harming the environment [7]. Moreover, polybag needs to be removed before transplanting, which potentially causes root damage and is considerably time-consuming leading to higher labor cost. Plantable containers, using biodegradable materials, could reduce transplanting shock, limit root damage, and decrease the time for plants to adapt in the plantation [9-11].

Biodegradable seedling pot (BioPot) is proposed as a positive breakthrough to deal with environmental risk caused by the use of polybags. Numerous studies and patent on biodegradable materials used in the seedling pot had been done in recent years, namely biopolymer e.g polyamide, polylactic, polyurethane, and polyhydroxyalkanoate [12] and various natural fibers such as paper, corn stover, corn stalk, rice straw, rice husk, lignin, peat, wood, coconut coir, tomato waste (peel and seed), banana peel, and water hyacinth [13-18]. The alternative container from bio-based materials also showed satisfactory results on the plant growth compared to the polybag (polyethylene) [14, 19-20]. Although there have been many materials proposed for BioPot, it is mainly containing fiber without any nutrient addition, except the study reported by Tian et al. [17] which added cow manure. In this current research, abundant and low-cost natural fibers i.e water hyacinth and banana pseudostem as well as manure as nutrient sources 
were tested and optimized to produce good quality papaya seedling. This research is expected to share information on the use of biodegradable seedling pot for horticultural crops, especially fruits, so the adoption of biodegradable containers as an alternative and substitute for plastic containers can be improved [11]. The objective of this research was to optimize the BioPot compositions made from water hyacinth and banana pseudostem with nutrient addition for papaya (Carica papaya L.) nursery.

\section{MATERIALS AND METHODS}

The research was conducted in a greenhouse of the Agrotechnology Department, University of Muhammadiyah Malang. The materials used in this research were water hyacinth, banana pseudostem, manure (goat, chicken, and cow), and paitan (Tithonia diversifolia). The procedures of making BioPot comprised cutting and weighing, pulping, molding, and drying as explained by Darmansyah [21].

\subsection{Experimental design}

This experiment was conducted using simple Randomized Complete Block Design (RCBD) with 1 control, 7 treatments, and 3 replications. The control was BioPot made from 60\% water hyacinth and $40 \%$ banana pseudostem (based on a study reported by Darmansyah (2016)) and the treatments were BioPot made from 50\% water hyacinth, $40 \%$ banana pseudosteam, and $10 \%$ nutrient sources in the form of manure or organic fertilizer (chicken, goat, cow, and or paitan). The compositions variety of BioPot shown in Table 1.

Table 1: Composition variety of BioPot

\begin{tabular}{|c|c|c|c|c|c|c|}
\hline \multirow{2}{*}{$\begin{array}{l}\text { Treatment } \\
\text { code* }\end{array}$} & \multirow{2}{*}{$\begin{array}{c}\text { WH } \\
\text { (water hyacinth) } \\
(\%)\end{array}$} & \multirow{2}{*}{$\begin{array}{c}\text { BS } \\
\text { (banana } \\
\text { pseudostem) }(\%)\end{array}$} & \multicolumn{4}{|c|}{ Materials of manure/organic fertilizer (\%) } \\
\hline & & & $\begin{array}{c}\text { Ch } \\
\text { (chicken) }\end{array}$ & $\begin{array}{c}\text { G } \\
\text { (goat) }\end{array}$ & $\begin{array}{c}\mathrm{C} \\
(\text { cow })\end{array}$ & $\begin{array}{c}\mathbf{P P} \\
\text { (Paitan) }\end{array}$ \\
\hline $\mathrm{P}$ (control) & 60 & 40 & - & - & - & - \\
\hline $\mathrm{PCh}$ & 50 & 40 & 10 & - & - & - \\
\hline $\mathrm{PC}$ & 50 & 40 & - & 10 & - & - \\
\hline PG & 50 & 40 & - & - & 10 & - \\
\hline PP & 50 & 40 & - & - & - & 10 \\
\hline PChG & 50 & 40 & 5 & 5 & - & - \\
\hline $\mathrm{PChC}$ & 50 & 40 & 5 & - & 5 & - \\
\hline PChPP & 50 & 40 & 5 & - & - & 5 \\
\hline
\end{tabular}

*P (control), the treatment included the composition of water hyacinth: banana pseudostem: manure (percentage and type) to obtain $100 \%$ material composition labelled as PCh, PC, PG, PP, PChC, PCG, and PChP. P stands for water hyacinth and banana pseudotem composition, and the next letter stands for the type of manure/organic 
fertilizer.

\subsection{Observation and Measured Variables}

The variables observed included root penetration (day); height of seedling $(\mathrm{cm})$, number of leaves (blade), and diameter of stem $(\mathrm{mm})$, length of root $(\mathrm{cm})$, dry weight $(\mathrm{g})$, and weight of root $(\mathrm{g})$. Root penetration (time to roots penetrated the BioPot), plant height (from soil surface to tip of growing point), number of leaves (on fully formed and opened leaf), and stem diameter (diameter of root collar) were measured once a week. Length of root was measured from the root tip to root collar at the end of the seedling observation. Shoot dry weight and root dry weight were weighed after water content was removed by drying (oven-dried until the weight was constant).

\subsection{Data Analysis}

The data were analyzed using ANOVA, then by means of Tukey HSD test ( $\alpha$ 5\% level of significance) to find out the best treatment. Correlation analysis was performed to understand the relationship among seedling growth variables. Response surface analysis was done to optimize the composition of BioPot towards papaya seedling growth as response variable.

\section{RESULTS}

The treatments of BioPot with various compositions have shown insignificantly different $(P>0.05)$ results of plant height compared to that of the control. Nevertheless, the treatments of PCh and PP have depicted a prominent difference, specifically from 21 to 28 days after planting. The average plant heights from 7 to 28 days after planting observation are shown in Fig. 1.

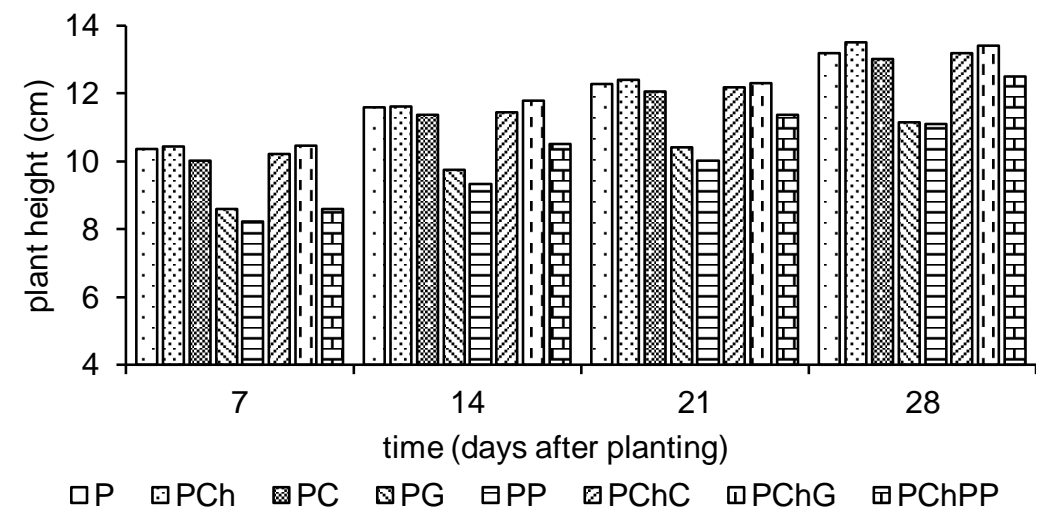

Fig. 1: Seedling height of papaya (Carica papaya L.) grown in various BioPot compositions on 7 until 28 days after planting. 
The treatments of various BioPot compositions also showed an insignificant difference $(P>0.05)$ in terms of the number of leaves during the observation. This was in line with a research brought up by Arvind (2014) showing that different containers would not give any significant influence on the number of leaves of papaya seedlings as illustrated in Fig. 2.

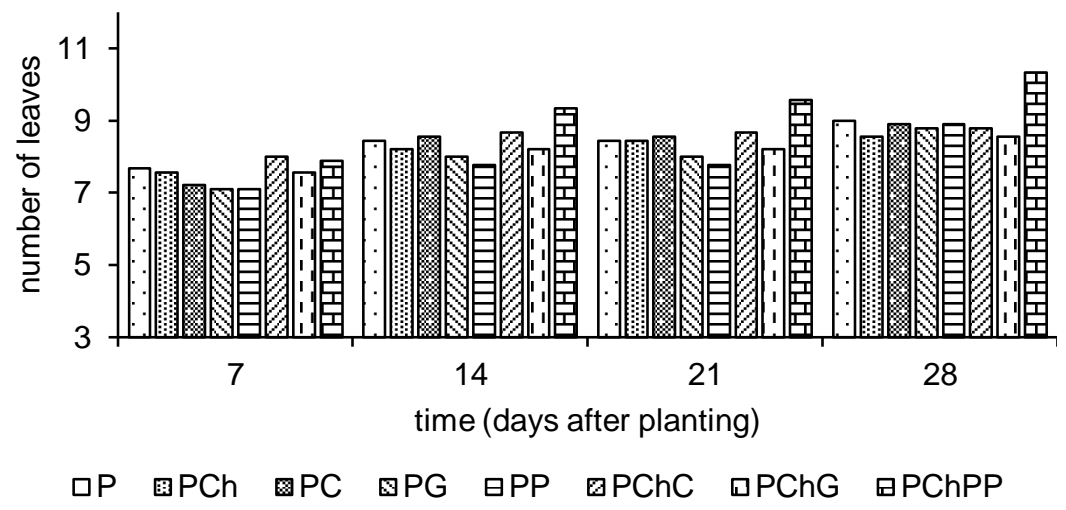

Fig. 2: Number of Papaya leaves (Carica papaya L.) grown in various BioPot compositions on 7 until 28 days after planting

The average stem diameters of papaya grown in various BioPot compositions during the observation period are illustrated in Fig. 3. The treatments of various BioPot compositions did not show a high difference in stem diameter of papaya seedling. At the end of the observation, the highest difference was about $0.75 \mathrm{~mm}$, so seedling produced from various BioPot compositions was in uniformly similar stem diameter.

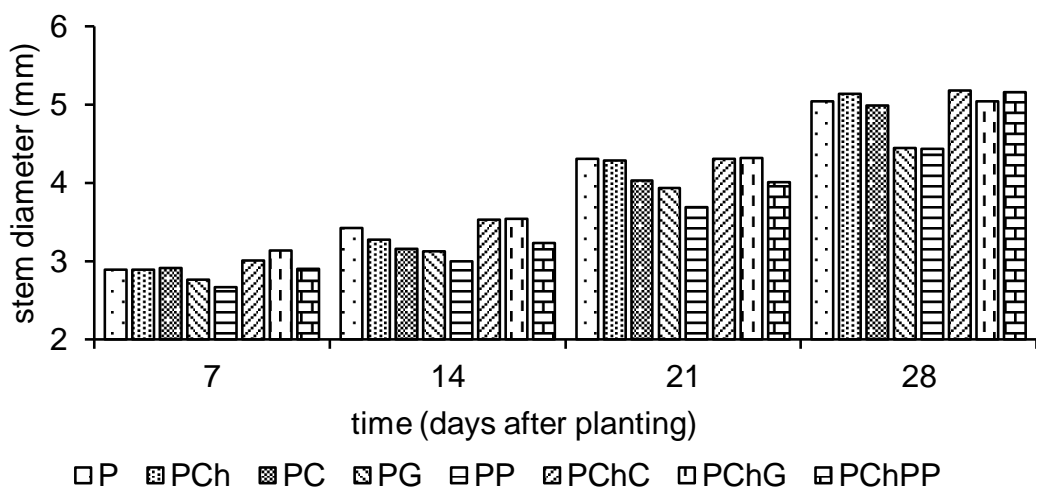

Fig. 3: Stem diameter of Papaya (Carica papaya L.) grown in various BioPot compositions on 7 until 28 days after planting 
International Journal of Agriculture and Environmental Research

ISSN: 2455-6939

Volume: 07, Issue: 05 "September-October 2021"

Table 2: Length of root penetration of papaya seedlings based on periodical observation

\begin{tabular}{llccc}
\hline & \multicolumn{3}{c}{ Length of observation (days after planting) } \\
\cline { 2 - 5 } & $\mathbf{7}$ & $\mathbf{1 4}$ & $\mathbf{2 1}$ & $\mathbf{2 8}$ \\
\hline P (WH:60\%, BS:40\%) & - & - & penetrating & penetrating \\
PCh $(\mathrm{WH}: 50 \%, \mathrm{BS}: 40 \%, \mathrm{Ch}: 10 \%)$ & - & - & penetrating & penetrating \\
PC (WH:50\%, BS:40\%, C:10\%) & - & - & penetrating & penetrating \\
PG (WH:50\%, BS:40\%, G:10\%) & - & - & penetrating & penetrating \\
PP (WH:50\%, BS:40\%, P:10\%) & - & - & penetrating & penetrating \\
PChC (WH:50\%, BS:40\%, C:5\%, Ch:5\%) & - & - & penetrating & penetrating \\
PChG (WH:50\%, BS:40\%, Ch:5\%, G:5\%) & - & - & penetrating & penetrating \\
PChPP (WH:50\%, BS:40\%, Ch:5\%, P:5\%) & - & - & penetrating & penetrating \\
\hline *WH: water hyacinth, BS: banana pseudostem, Ch: chicken manure, C: cow manure, G: goat manure, PP: \\
Paitan compost
\end{tabular}

The lengths of root penetration of papaya seedling during the observation period are shown in Table 2. The root was starting to penetrate the BioPot in 21 days after planting which means that the BioPot did not inhibit the growth and development of roots.

\section{Table 3: Biomass and dry matter of papaya seedling grown in BioPot atthe end of observation}

\begin{tabular}{lcccccc}
\hline Treatments* & $\begin{array}{c}\text { Seedling } \\
\text { height } \\
(\mathbf{c m})\end{array}$ & $\begin{array}{c}\text { Number } \\
\text { of leaves }\end{array}$ & $\begin{array}{c}\text { Stem } \\
\text { diameter } \\
(\mathbf{m m})\end{array}$ & $\begin{array}{c}\text { Length of } \\
\text { root }(\mathbf{c m})\end{array}$ & $\begin{array}{c}\text { Dry weight } \\
\text { of root }(\mathbf{g})\end{array}$ & $\begin{array}{c}\text { Dry weight } \\
\text { of shoot }(\mathbf{g})\end{array}$ \\
\hline P (control) & $13.20 \mathrm{ab}^{* *}$ & $9.00 \mathrm{a}$ & $5.04 \mathrm{a}$ & $11.72 \mathrm{a}$ & $0.26 \mathrm{a}$ & $0.63 \mathrm{a}$ \\
PCh & $13.50 \mathrm{~b}$ & $8.56 \mathrm{a}$ & $5.14 \mathrm{a}$ & $12.32 \mathrm{a}$ & $0.22 \mathrm{a}$ & $0.64 \mathrm{a}$ \\
PC & $13.02 \mathrm{ab}$ & $8.89 \mathrm{a}$ & $4.99 \mathrm{a}$ & $12.09 \mathrm{a}$ & $0.25 \mathrm{a}$ & $0.55 \mathrm{a}$ \\
PG & $11.16 \mathrm{ab}$ & $8.78 \mathrm{a}$ & $4.44 \mathrm{a}$ & $11.80 \mathrm{a}$ & $0.22 \mathrm{a}$ & $0.45 \mathrm{a}$ \\
PP & $11.10 \mathrm{a}$ & $8.89 \mathrm{a}$ & $4.43 \mathrm{a}$ & $11.00 \mathrm{a}$ & $0.18 \mathrm{a}$ & $0.45 \mathrm{a}$ \\
PChG & $13.20 \mathrm{ab}$ & $8.78 \mathrm{a}$ & $5.18 \mathrm{a}$ & $11.12 \mathrm{a}$ & $0.21 \mathrm{a}$ & $0.55 \mathrm{a}$ \\
PChC & $13.42 \mathrm{ab}$ & $8.56 \mathrm{a}$ & $5.04 \mathrm{a}$ & $11.70 \mathrm{a}$ & $0.22 \mathrm{a}$ & $0.63 \mathrm{a}$ \\
PChPP & $12.50 \mathrm{ab}$ & $10.33 \mathrm{a}$ & $5.16 \mathrm{a}$ & $11.97 \mathrm{a}$ & $0.26 \mathrm{a}$ & $0.64 \mathrm{a}$ \\
\hline
\end{tabular}

**The average values with the same letter and in the same column show insignificant difference based on HSD test with $\alpha 5 \%$ level of significance $(P>0.05)$.

*P (control: $60 \%$ water hyacinth and $40 \%$ banana pseudostem), treatments: $\mathrm{P}$ and nutrient addition labelled as Ch:chicken manure, C: cow manure, G: goat manure, PP: Paitan compost.

Table 3 shows the average lengths of root, dry weight of root, and dry weight of stem in 28 days after planting. The results of the observation have shown that the length of root ranged between 
11-11.97 cm, the dry weight of root between 0.18-0.26 g, and the dry weight of stem between 0.45-0.64 g. Biomass and dry matter of papaya seedling were observed at the end of the period and the difference among BioPot compositions was not seen (Table 3). Nevertheless, BioPot with chicken manure and or paitan as nutrient sources showed relatively more numbers of leaves, wider stem diameter, higher seedling height and length of root, and heavier dry weight of root stem than the other treatments.

Referring to the correlational analysis among the variables under the observation, there were obviously positive correlations, namely: 1 ) between the height of the plant and the diameter and dry weight of stem; 2) between the number of leaves and the dry weight of stem; 3 ) between the diameter of stem and the dry weight of stem; and 4) between the dry weight of root and the dry weight of stem. It is evident that to gain biomass, the shoot part should be supported by the root transplanted in the subsurface side of the media. Now that there was no significant difference in root growth (the subsurface of growing medium), the shoot parts also showed insignificant results. The optimum composition of BioPot for papaya nursery can be obtained using response surface analysis.
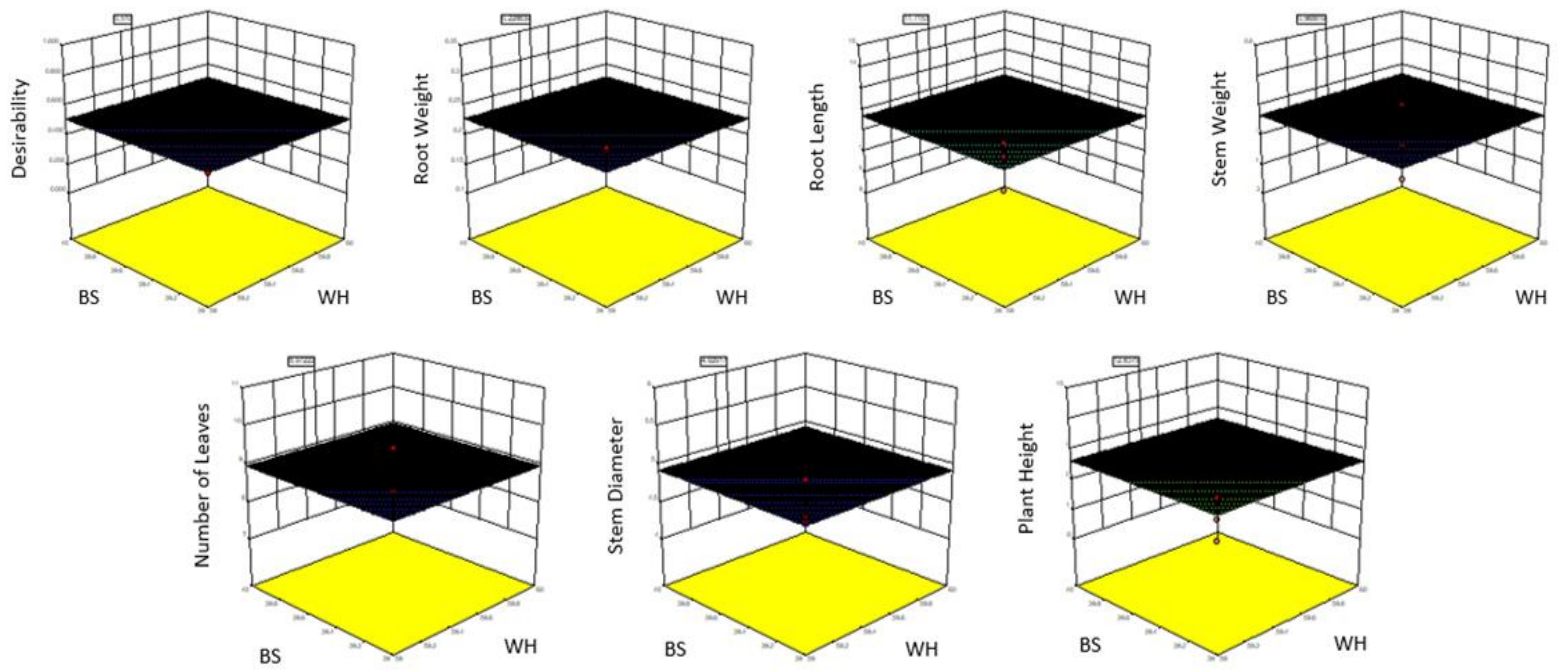

Fig. 4: Optimation of BioPot for the growth of papaya seedling

Optimation of the growth of papaya seedling as a response variable is presented in Fig. 4. It is shows that the optimation results from all response variables formed a relatively flat curve. It has indicated that the obtained response has reached optimum results at all treatment levels. Furthermore, the desirability value of 100 optimum solutions was 0.51 and the prediction responses were relatively similar. It has proven that the compositions of BioPot have reached the optimum results of papaya seedling growth. The compositions of BioPot have been predicted to obtain the responses of papaya seedling growth for about $0.23,11.72,0.57,8.97,4.93$, and 12.64 
International Journal of Agriculture and Environmental Research

ISSN: 2455-6939

Volume: 07, Issue: 05 "September-October 2021"

for root weight, root length, shoot weight, number of leaves, stem diameter, and plant height respectively (Table 4).

Table 4: Optimum solution of papaya seedling growth

\begin{tabular}{ccccccccccc}
\hline No & \% WH* \% BS* & Manure* & $\begin{array}{c}\text { Root } \\
\text { weight }\end{array}$ & $\begin{array}{c}\text { Root } \\
\text { length }\end{array}$ & $\begin{array}{c}\text { Shoot } \\
\text { weight }\end{array}$ & $\begin{array}{c}\text { Number } \\
\text { of leaves }\end{array}$ & $\begin{array}{c}\text { Stem } \\
\text { diameter }\end{array}$ & $\begin{array}{c}\text { Plant } \\
\text { height }\end{array}$ & D \\
\hline 1 & 59.51 & 39.10 & Ch1\%:PP1\% & 0.23 & 11.72 & 0.57 & 8.97 & 4.93 & 12.64 & 0.51 \\
2 & 59.00 & 40.00 & Ch1\% & 0.23 & 11.72 & 0.57 & 8.97 & 4.93 & 12.64 & 0.51 \\
3 & 59.00 & 39.00 & Ch1\%:G1\% & 0.23 & 11.72 & 0.57 & 8.97 & 4.93 & 12.64 & 0.51 \\
4 & 59.00 & 40.00 & PP1\% & 0.23 & 11.72 & 0.57 & 8.97 & 4.93 & 12.64 & 0.51 \\
5 & 60.00 & 40.00 & Control & 0.23 & 11.72 & 0.57 & 8.97 & 4.93 & 12.64 & 0.51 \\
6 & 59.00 & 39.00 & Ch1\%:C1\% & 0.23 & 11.72 & 0.57 & 8.97 & 4.93 & 12.64 & 0.51 \\
7 & 59.00 & 40.00 & G1\% & 0.23 & 11.72 & 0.57 & 8.97 & 4.93 & 12.64 & 0.51 \\
8 & 59.00 & 39.00 & Ch1\%:PP1\% & 0.23 & 11.72 & 0.57 & 8.97 & 4.93 & 12.64 & 0.51 \\
9 & 59.75 & 39.63 & Control & 0.23 & 11.72 & 0.57 & 8.97 & 4.93 & 12.64 & 0.51 \\
10 & 59.82 & 39.67 & Control & 0.23 & 11.72 & 0.57 & 8.97 & 4.93 & 12.64 & 0.51 \\
$\vdots$ & $\vdots$ & $\vdots$ & $\vdots$ & $\vdots$ & $\vdots$ & $\vdots$ & $\vdots$ & $\vdots$ & $\vdots$ & $\vdots$ \\
100 & 59.46 & 39.66 & Control & 0.23 & 11.72 & 0.57 & 8.97 & 4.93 & 12.64 & 0.51 \\
\hline
\end{tabular}

*WH: Water hyacinth; BS : Banana stem; D : Desirability

\section{DISCUSSION}

BioPot made from water hyacinth and banana pseudostem has been researched by Darmansyah [21] and the combination of water hyacinth and coconut coir was also studied by Iriany et al. [18] and it turned out that the composition of $60 \%$ water hyacinth and $40 \%$ banana pseudostem or coconut coir exhibited satisfying seedling growth, plant growth, and yield of chili. The addition of nutrient sources was projected in this current research. In general, although BioPot with the addition of chicken manure and or paitan showed relatively better seedling growth (higher means of growth variables) than the other treatments, the results showed that nutrient sources did not significantly affect seedling growth of papaya. It can be explained by the contents of the nutrient sources, e.g potassium. Potassium contributes to ion absorption and transportation, protein synthesis, osmotic pressure, as well as tissue structure through turgor pressure and cell dilation [22]. In addition, potassium is an important element for stem and cell development which might affect the growth of the stem seedling [3]. Chicken manure and T. diversifolia contain higher nutrients (nitrogen, potassium, organic carbon, and organic matter) than cow and goat manures [24]. Chicken manure comprises $27.02 \% \mathrm{C}, 5.3 \% \mathrm{~N}, 2.5 \% \mathrm{P}_{2} \mathrm{O}_{5}$, and $2.09 \% \mathrm{~K}$ [25]; while $T$. diversifolia biomass consists of $31.76 \% \mathrm{C}, 54.91 \%$ organic matter, $3.1-4.46 \% \mathrm{~N}, 0.37-0.61 \% \mathrm{P}$, and 3.75-4.1\% K [26-29]. Meanwhile, sheep and goat manures contain 19.58-30.61\% C, 1.56$2.32 \% \mathrm{~N}, 0.77-3.00 \% \mathrm{~K}$, and 9.52-26.50\% ash [30]. According to Santillán and Moreno [31] and 
International Journal of Agriculture and Environmental Research

ISSN: 2455-6939

Volume: 07, Issue: 05 "September-October 2021"

Ksheem and Antille [32], the nutrient composition in cow manure consists of 15.13-11.59\% of P-available, 57.5\% C-total, 9.53\% N-total, and $13.35 \% \mathrm{~K}$-total; while some studies reported that cow or cattle manure contains $8.0-16.6 \% \mathrm{C}, 0.95-2.87 \% \mathrm{~N}, 0.31-0.86 \%$ P-total, and $0.27-0.64 \%$ K-total [25, 28, 33-34]. The difference of nutrient composition in manure depends on the chemical composition of feed sources and total food intake [30].

The insignificant difference of nutrient sources in BioPot during the seedling growth observation can be explained through the studies reported by Dominguez-Lerena et al. [35] and Bali et al.[36]. The seedling growth is influenced more by seedling container diameter, depth, volume, and growing density than container type. The nutrient addition could affect the seedling growth after the seedling was transplanted and the nutrient was released from the BioPot. Furthermore, BioPot also has a good water absorption capacity due to its high organic matter contents. Hafifah et al.[28] stated that $T$. diversifolia significantly increased soil water holding capacity. Plug-cell from cow manure has the best performance in terms of water absorption, tensile strength, and biodegradability compared to wood fiber and peat moss [37]. BioPot has offered better drainage and aeration for the root growth. Besides, all BioPot compositions in this research support root growth and development with good branching structure and secondary root, indicated by the root growth variable and the time for the root to penetrate BioPot in 21 days after sowing; and the BioPot remained intact until the end of the observation. It has been verified that root restriction and deformation will not occur after the transplantation of seedling [13].

Response surface analysis is frequently used for the optimization of compositions and processes of making numerous products such as bioplastic, biodegraded composite, and biodegradable aliphatic-aromatic polyester films [36-37]. The response variables included root weight, root length, shoot weight, number of leaves, stem diameter, and plant height. This research has revealed that the combination of water hyacinth, banana pseudostem, and nutrient enrichment using manure as BioPot materials for papaya nursery has shown optimal growth response based on the response analysis.

\section{CONCLUSION}

The various BioPot compositions have demonstrated no significant difference in papaya seedling growth during the papaya nursery stage. The optimation results also formed relatively flat curve from all response variables, indicating that the obtained response has reached the optimum results in all BioPot compositions with various nutrient sources. It is confirmed that various nutrient sources can be added into BioPot formulation considering the availability and accessibility of the local nutrient sources. Although there was no significant growth difference among BioPot compositions and the optimum composition had been reached from all treatments, 
International Journal of Agriculture and Environmental Research

ISSN: 2455-6939

Volume: 07, Issue: 05 "September-October 2021"

BioPot with the nutrient addition of chicken manure and or Tithonia diversifolia showed relatively higher seedling growth than the other nutrient sources.

\section{ACKNOWLEDGEMENTS}

We would like expressed our gratitude to the Agrotechnology Department, Faculty of Agriculture and Animal Husbandry, University of Muhammadiyah malang for supporting us conducted this research.

\section{REFERENCES}

[1] FAO. (2019) Area harvested, Production and yield of papaya in the world based on Country between 2015-2017, Crops (production).https://www.fao.org/faostat

[2] BPS. (2019) Tabel Ekspor Menurut Komoditi Tahun 2015-2017.https://bps.go.id

[3] Sakthivel, C. (2009). Standarization of Nursery Techniques for Papaya (Carica papaya L.) CV. Solo and Acid Lime (Citrus aurantifolia Swingle L.). University of Agricultural Science.https://krishikosh.egranth.ac.in/displaybitstream?handle=1/5810022663

[4] Lestari, P.; Trihadiningrum, Y., (2019). The impact of improper solid waste management to plastic pollution in Indonesian coast and marine environment. Mar. Pollut. Bull., 149: 110505. https://www.sciencedirect.com/science/article/abs/pii/S0025326X19306435?via\%3Dihub

[5] Thushari, G.G.N.; Senevirathna, J.D.M., (2020). Plastic pollution in the marine environment. Heliyon, 604709. https://www.sciencedirect.com/science/article/pii/S2405844020315528

[6] Wanner, P. (2021). Plastic in agricultural soils - A global risk for groundwater systems and drinking water supplies? - A review. Chemosphere, 264: 128453. https://www.sciencedirect.com/science/article/pii/S0045653520326485.

[7] Kasirajan, S.; Ngouajio, M., (2012). Polyethylene and biodegradable mulches for agricultural applications: A review. Agro. Sustain. Dev., 32(2): 501-529. https://link.springer.com/article/10.1007/s13593-011-0068-3

[8] Nambuthiri, S.; Fulcher, A.; Koeser, A.K.; Geneve, R.; Niu, G., (2015). Moving toward sustainability with alternative containers for greenhouse and nursery crop production: A review and research update. HortTechnology, 25(1): 8-16. https://journals.ashs.org/horttech/downloadpdf/journals/horttech/25/1/article-p8.xml

[9] Balestri, E.; Vallerini, F.; Seggiani, M.; Cinelli, P.; Menicagli, V.; Vannini, C., Lardicci, C., (2019). Use of bio-containers from seagrass wrack with nursery planting to improve the eco-sustainability of coastal habitat restoration. J. Environ. Manage., 251: 109604. https://www.sciencedirect.com/science/article/pii/S0301479719313222 
International Journal of Agriculture and Environmental Research

ISSN: 2455-6939

Volume: 07, Issue: 05 "September-October 2021"

[10] Harris, B.A.; Florkowski, W.J.; Pennisi, S.V., (2020). Horticulture industry adoption of biodegradable containers. HortTechnology, 30(3): 372-384. https://journals.ashs.org/horttech/downloadpdf/journals/horttech/30/3/article-p372.xml

[11] Kratsch, H.A.; Schrader, J.A.; McCabe, K.G.; Srinivasan, G.; Grewell, D.; Graves, W.R., (2015). Performance and biodegradation in soil of novel horticulture containers made from bioplastics and biocomposites. HortTechnology, 25(1): 119-131. https://journals.ashs.org/horttech/downloadpdf/journals/horttech/25/1/article-p119.xml

[12] Schettini, E.; Santagata, G.; Malinconico, M.; Immirzi, B.; Mugnozza, G.S.; Vox, G., (2013). Recycled wastes of tomato and hemp fibres for biodegradable pots: Physicochemical characterization and field performance. Resour. Conserv. Recycl., 70: 9-19. https://www.sciencedirect.com/science/article/abs/pii/S0921344912002017

[13] McCabe, K.G.; Schrader, J.A.; Madbouly, S.; Grewell, D.; Graves, W.R., (2014). Evaluation of biopolymer-coated fiber containers for container-grown plants. HortTechnology, 24(4): 439-448. https://journals.ashs.org/horttech/downloadpdf/journals/horttech/24/4/article-p439.xml

[14] Schrader, J.A.; McCabe, K.G.; Srinivasan, G.; Haubrich, K.; Grewell, D.; Madbouly, S.; Graves, W., (2015). Development and evaluation of bioplastic containers for sustainable greenhouse and nursery production. Acta Hortic., 1140 (XXIX IHC - Proc. Int. Symp. on Ornamental Horticulture in the Global Greenhouse).https://www.actahort.org/members/showpdf?booknrarnr=1104_13

[15] Mohd Rafee, S.N.A.; Lee, Y.L.; Jamaluddin, M.R.; Abdul Razak, N.; Makhtar, N.L.; Ismail, R.I., (2019). Effect of different ratios of biomaterials to banana peels on the weight loss of biodegradable pots. Acta Technol. Agric., 22(1): 1-4. https://content.sciendo.com/downloadpdf/journals/ata/22/1/article-p1.xml

[16] Tian, M.; Gao, J.; Liang, H., (2019). Preparation and performance of biomass seedling containers made with straw and cow manure. BioResources, 14(4): 9968-9980. https://ojs.cnr.ncsu.edu/index.php/BioRes/article/view/BioRes_14_4_9968_Tian_Performa nce_Biomass_Seedling_Containers/7275

[17] Iriany, A.; Sari, O.A.W.; Hasanah, F., (2020). Optimization of BioPot compositions made from water hyacinth and coconut coir for improving the growth and yield of chili (Capsicum annum L.). Int. J. Recycl. Org. Waste Agric., 9(3): 287-296. http://ijrowa.khuisf.ac.ir/article_674661_3cf8a00c61cb6d04fcdd9952c22f4a4c.pdf

[18] Kuehny, J.S.; Taylor, M.; Evans, M.R., (2011). Greenhouse and landscape performance of bedding plants in biocontainers. HortTechnology, 21(2): 155-161. https://journals.ashs.org/horttech/downloadpdf/journals/horttech/21/2/article-p155.xml 
International Journal of Agriculture and Environmental Research

ISSN: 2455-6939

Volume: 07, Issue: 05 "September-October 2021"

[19] Castronuovo, D.; Picuno, P.; Manera, C.; Scopa, A.; Sofo, A.; Candido, V., (2015). Biodegradable pots for poinsettia cultivation: Agronomic and technical traits. Sci. Hortic., 197: 150-156. https://www.sciencedirect.com/science/article/abs/pii/S0304423815301898

[20] Darmansyah (2016) Kajian Penggunaan Kantong Tanam Organik Berbahan Dasar Enceng Gondok Dan Pelepah Batang Pisang Pada Pembibitan Cabai Merah (Capsicum Annuum L.). Universitas Muhammadiyah Malang.http://eprints.umm.ac.id/

[21] Mengel, K. (2007). Potassium. in Barker, A.V. and Pilbeam, D.J. (eds) Handbook of Plant nutrition. Boca Raton: CRC Press, Taylor and Francis Group.https://www.springer.com/gp/book/9780792371502

[22] Maghfoer, M.D.;Prasetya, B., (2016). The potential of Tithonia diversifolia green manure for improving soil quality for cauliflower (Brassica oleracea var . Brotrytis L.). J. Degrad. Min. Lands Manag., 3(2): 499-506. https://www.jdmlm.ub.ac.id/index.php/jdmlm/article/view/159

[23] Huang, J.; Yu, Z.; Gao, H.; Yan, X.; Chang, J.; Wang, C.; Hu, J.; Zhang, L., (2017). Chemical structures and characteristics of animal manures and composts during composting and assessment of maturity indices. PLoS One, 12(6): e0178110. https://journals.plos.org/plosone/article?id=10.1371/journal.pone.0178110

[24] Kipot, E. (2008). Adoption dynamics of Tithonia diversifolia for soil fertility management in pilot villages of Western Kenya. Expl. Agric., 44: 473484.https://www.cambridge.org/core/journals/experimentalagriculture/article/abs/adoption-dynamics-of-tithonia-diversifolia-for-soil-fertilitymanagement-in-pilot-villages-of-westernkenya/5178771A2EFCA3AB60C9BF636F1F73EA

[25] Mwangi, P.; Mathenge, P., (2014). Comparison of tithonia (Tithonia diversifolia) green manure, poultry manure and inorganic sources of nitrogen in the growth of kales (Brassicae oleraceae) in Nyeri County, Kenya. African J. Food, Agric. Nutr. Dev., 14(3): 8791-8808. https://www.ajol.info/index.php/ajfand/article/view/104794/94832

[26] Hafifah, Sudiarso, Maghfoer, M., Prasetya, B., (2016). The potential of Tithonia diversifolia green manure for improving soil quality for cauliflower (Brassica oleracea var . Brotrytis L.). J. Degrad. Min. Lands Manag., 3(2): 499-506. https://jdmlm.ub.ac.id/index.php/jdmlm/article/view/159/pdf

[27] Dayo-Olagbende, G.; Akingbola, O.; Ewulo, B., (2020). Influence of Tithonia Diversifolia on maize (Zea mays L.) yield, fertility and infiltration status of two clay varied soils. Int. Ann. Sci., 8(1): 114-119.https://journals.aijr.in/index.php/ias/article/view/1897/260

[28] Ansah, K.O.; Antwi, C., Osafo, E.L.K.; Enning, S.; Adu-Dapaah, H., (2019). Manure characteristics of small ruminants fed agroby- products in the guinea savannah agro- 
International Journal of Agriculture and Environmental Research

ISSN: 2455-6939

Volume: 07, Issue: 05 "September-October 2021"

ecological zone of Ghana. Ghana J. Agric. Sci., 54(1): 67-76. https://www.ajol.info/index.php/gjas/article/view/189822/179040

[29] Santillán, Y.M.; Moreno, F.P. (2014). Effect of the application of manure of cattle on the properties chemistry of soil in Tizayuca, Hidalgo, Mexico. Int. J. Appl. Sci. Tech., 4(3): $67-72$.

https://www.researchgate.net/profile/Fidel_Perez3/publication/263852103_Effect_of_the Application_of_Manure_of_Cattle_on_the_Properties_Chemistry_of_Soil_in_Tizayuca_H idalgo_Mexico_Introduction/links/00b4953c1e6bb94cb3000000/Effect-of-the-

Application-of-Manure-of-Cattle-on-the-Properties-Chemistry-of-Soil-in-TizayucaHidalgo-Mexico-Introduction.pdf

[30] Ksheem, A.M.;Antille, D.L., (2016). Nutrient composition and nutrient losses during composting of chicken manures as affected by addition of sawdust. in 4th International Conference on Sustainable Solid Waste Management. Limassol.http://uest.ntua.gr/cyprus2016/proceedings/pdf/Ksheem_Antille_nutrient_compo sition_losses_during_composting.pdf

[31] Khater, E.G. (2015). Some physical and chemcial properties of compost. Int. J. Waste Resour., 5(1): 1-5. https://www.longdom.org/open-access/some-physical-and-chemicalproperties-of-compost-2252-5211-1000172.pdf

[32] Manitoba (2015). Properties of Manure. Manitoba Agricuture, Food and Rural development.

https://www.gov.mb.ca/agriculture/environment/nutrientmanagement/pubs/properties-of-manure.pdf

[33] Dominguez-Lerena, S.; Herrero Sierra, N.; Carrasco, M.I., Ocaña Bueno, L.; Peñuelas, R.J.L.; Mexal, J.G., (2006). Container characteristics influence Pinus pinea seedling development in the nursery and field. For. Ecol. Manage., 221(1-3): 63-71. https://www.sciencedirect.com/science/article/abs/pii/S0378112705004974

[34] Bali, R.S.; Chauhan, D.S.; Todaria, N.P., (2013). Effect of growing media, nursery beds and containers on seed germination and seedling establishment of Terminalia bellirica (Gaertn.) Roxb ., a multipurpose tree. Trop. Ecol., 54(1): 59-66. http://www.tropecol.com/pdf/open/PDF_54_1/5-Rawat, Joshi \& Mesia.pdf

[35] Zhang, X.; Wang, C.; Chen, Y., (2019). Properties of selected biodegradable seedling plugtrays. Sci. Hortic., 249: 177-184. https://www.sciencedirect.com/science/article/abs/pii/S0304423819300706

[36] Kijchavengkul, T. (2010). Design of biodegradable aliphatic aromatic polyester films for agricultural application using response surface methodology. Michigan State University.http://d.lib.msu.edu/etd/1527/datastream/OBJ/View/.

[37] Araújo, C.S.; Rodrigues, A.M.C.; Joele, M.R.S.P.; Araújo, E.A.F.; Lourenço, L.F.H., (2018). Optimizing process parameters to obtain a bioplastic using proteins from fish 
International Journal of Agriculture and Environmental Research

ISSN: 2455-6939

Volume: 07, Issue: 05 "September-October 2021"

byproducts through the response surface methodology. Food Packag. Shelf Life, 16: 2330. https://www.sciencedirect.com/science/article/abs/pii/S2214289417301163 